\title{
STRATEGI PELESTARIAN PERALATAN DAN INFRASTRUKTUR PERTAMBANGAN MINYAK DARI MASA KOLONIAL DI SANGASANGA KALIMANTAN TIMUR
}

\section{CONSERVATION STRATEGY ON THE EQUIPMENTS AND INFRASTRUCTURES OF COLONIAL OIL MINING IN SANGASANGA, EAST KALIMANTAN}

\author{
Wasita \\ Balai Arkeologi Banjarmasin \\ Jalan Gotong Royong II, Rt03, Rw 06, Mentaos, Banjarbaru, Kalimantan Selatan 70711 \\ e-mail: wasita6@yahoo.com
}

Naskah diterima tanggal: 18/06/2015, Direvisi akhir tanggal: 01/03/2016, disetujui tanggal: 14/03/2016

\begin{abstract}
The study aimed to obtain a proper strategy in the preservation of colonial archaeological remains in Sangasanga with community involvement. Therefore, the method used was a descriptive analysis by providing a complete picture of archaeological data. The result shows that the most effective preservation is by involving local community. In this case, people are not merely engaged to work but a system is made which conducts utilization concept and has additional value to earn profit. Utilization of occupying the building (for example komplak) and earned income are through economic activities related to cultural heritage tour. Hopefully, involving local people in the conservation will be easily realized through the activities. Nevertheless, the system could not be allowed to work alone. There should be monitoring and evaluation in order to implement conservation habits become an attitude of life. The conclusion of this study is that the preservation action for oil company equipment and infrastructure in Sangasanga should promptly be done by conservation strategy with added values by involving the community.
\end{abstract}

Keywords: remains preservation, archaeological resource utilization, tourism, community involevement

\begin{abstract}
Abstrak: Penelitian ini bertujuan mengkaji strategi yang tepat dalam pelestarian peninggalan arkeologi kolonial di Sangasanga dengan melibatkan masyarakat. Untuk mendapatkan cara pelestarian yang tepat, dilakukan analisis deskriptif, yaitu dengan memberikan gambaran secara lengkap mengenai realitas tinggalan arkeologi yang dikaji. Hasil kajian ini menunjukkan bahwa pelestarian yang paling efektif adalah dengan cara melibatkan masyarakat. Dalam hal ini, masyarakat tidak semata-mata hanya dilibatkan untuk bekerja, tetapi dibuat program pelestarian yang berwawasan pemanfaatan dan bahkan ada nilai tambah bagi masyarakat, yaitu menjadi sumber penghasilan. Pemanfaatan dengan menempati bangunan (misalnya komplak) dan perolehan penghasilannya melalui kegiatan ekonomi yang berkaitan dengan wisata warisan budaya. Jika pola ini terbentuk, harapan agar keterlibatan masyarakat dalam pelestarian akan lebih mudah diwujudkan. Namun demikian, sistem itu tidak dapat dibiarkan bekerja sendiri dan harus ada pengawasan dan evaluasi, agar kebiasaan melaksanakan pelestarian menjadi sikap hidup masyarakat. Kesimpulan kajian ini adalah bahwa tindakan aksi pelestarian peralatan dan infrastruktur pertambangan minyak di Sangasanga dilakukan dengan strategi pelestarian yang berwawasan pemanfaatan dengan melibatkan masyarakat.
\end{abstract}

Kata kunci: pelestarian peninggalan sejarah, pemanfaatan sumberdaya arkeologi, pariwisata, keterlibatan masyarakat 


\section{Pendahuluan}

Peralatan pertambangan minyak masa kolonial di Sangasanga, Kabupaten Kutai Kartanegara, Kalimantan Timur dibangun pada masa Kerajaan Kutai Kartanegara tahun 1897. Pada saat itu, kolonial Belanda yang dipimpin J.H. Menten, tiba di Kutai Kartanegara dan mengadakan perjanjian dengan Raja Kutai Kartanegara untuk melakukan survei guna mengetahui potensi pertambangan dan kehutanan di wilayah kerajaan tersebut. Dalam perjanjian itu disebutkan bahwa jika survei berhasil menemukan tambang atau hasil hutan yang potensial, maka akan dilakukan penambangan ataupun penebangan kayu oleh Belanda. Menurut Ahyat (2013), dengan perjanjian tersebut, Sultan Kutai mendapat hak royalti dan pajak. Selain itu, J.H. Menten juga berjanji akan membayar biaya keamanan perusahaannya dan tidak akan menerima tenaga kerja orang-orang Cina yang berasal dari Bangka. Pengadaan buruh saat itu dilakukan dengan cara mendatangkan dari luar daerah bahkan luar negeri. Oost Borneo Maatschappij, pesaing perusahaan yang dikendalikan J.H Menten, pernah mendatang buruh China untuk meningkatkan produksinya (Ahyat, 2013). Hal ini menjadikan tersingkirnya tenaga kerja lokal.

Menindaklanjuti perjanjian tersebut, Belanda melakukan survei dan berhasil menemukan tambang minyak di Sangasanga. Selanjutnya, untuk kegiatan penambangan dilakukan kolonial Belanda melalui perusahaan NederlandschIndische Industrie en Handel Maatschappij (NIIHM) tahun1897-1905, dan kemudian Batavia Petroleum Maatschappij (BPM) tahun 1905-1942 yang mengalami perkembangan pesat, memasang peralatan tambang tambahan berupa pompa angguk (sucker rod pump) yang merupakan salah satu jenis pompa pada industri hulu migas dalam pengangkatan minyak bumi dari dalam sumur. Pompa ini bekerja menggunakan energi listrik atau gas, yang biasa digunakan pada sumur-sumur tua. Untuk memperlancar kegiatan penambangan, juga dibangun infrastruktur pertambangan berupa perkantoran, asrama para buruh, gedung untuk tempat perbaikan mesin (bengkel), tempat dan fasilitas olah raga, pelabuhan, instalasi pengolahan air bersih, gedung film, penjara, kantor pos (Tim Peneliti, 2008; Susanto, 2005), bahkan ada pula orang Belanda yang membangun rumah pribadi. Dalam perkembangannya, Sangasanga dikuasai oleh Jepang dan mereka melanjutkan eksplorasi minyak pada tahun 19421945 dan juga membangun infrasruktur baru, seperti tangsi dan Barak B 21 di Distrik IV, Sangasanga, Pembangkit Tenaga Listrik Elektra, serta tiga buah gua pertahanan/persembunyian. Selain itu, pejuang Indonesia juga pernah memanfaatkan titik-titik tertentu di Sangasanga untuk Kubu Pertahanan (Wasita dkk., 2012) dalam merebut kembali wilayah tersebut ke pangkuan Ibu Pertiwi.

Pada zaman kemerdekaan, Sangasanga menjadi bagian wilayah Negara Kesatuan Republik Indonesia (NKRI), dan pengelolaan tambang minyak dilakukan kembali oleh BPM (1945-1950) dan Pemerintah Indonesia (1950 sampai sekarang). Pada saat kendali pengelolaan minyak dipegang oleh Indonesia, konsesi tambang pernah juga dikuasakan kepada perusahaan asing, karena adanya pembelian. Setelah tahun 1950, secara berturut-turut penambangan di Sangasanga dilakukan oleh PT. Shell (perusahaan dari Inggris), Perusahaan Minjak Negara (Permina), Perusahaan Tambang Minyak Milik Negara (Pertamina), kemudian Tesoro Indonesia Petroleum, (1972-1992), Medco Energy Indonesia (1992-2008), dan Pertamina UBEP (Unit Bisnis, Eksplorasi dan Produksi) sejak tahun 2008 sampai sekarang.

Dalam perkembangannya, Sangasanga menjadi nama kecamatan yang juga merupakan wilayah hunian masyarakat dan berkembang menjadi permukiman kota kecamatan. Ada beberapa definisi kota, tetapi dalam konteks ini digunakan definisi Amos Rapopport seperti yang dikutip oleh Faisal dan Wihardyanto (2013) dan juga Wiraprama, dkk., (2014) yang mengatakan bahwa sebuah permukiman dapat dirumuskan sebagai sebuah kota, tidak didasarkan pada segi ciri-ciri morfologis tertentu, atau bahkan 
kumpulan ciri-cirinya, melainkan dari segi suatu fungsi khusus, yaitu sebuah wilayah yang menciptakan ruang-ruang efektif melalui pengorganisasian terhadap daerah pedalaman di sekitarnya berdasarkan hirarki-hirarki tertentu.

Dalam konteks ini, peralatan tambang dan seluruh infrastrukturnya (seperti yang disebutkan di atas), disebut sebagai tinggalan purbakala, tinggalan arkeologi, atau sumber daya arkeologi (SDA) dan tidak/belum disebut sebagai cagar budaya. Alasannya, objek yang dikaji sebagian besar belum mendapatkan penetapan sebagai cagar budaya, sedangkan yang sudah ditetapkan sebagai cagar budaya adalah gedung Sandisa, Monumen RIS, Kubu Pertahanan, Penjara, dan Tugu Pembantaian. Penggunaan tiga istilah itu dilakukan secara berganti-ganti untuk menghindari kejemuan. Keberadaan SDA tersebut pada saat ini terletak di Kota Kecamatan Sangasanga. Sebagai tempat bermukim, seluruh SDA di Sangasanga berada dalam konteks sistem. Pengertian konteks sistem menurut I Nyoman Wardi (2008) juga meliputi living monument yang terus dipelihara, dimodifikasi, dan didayagunakan oleh generasi berikutnya sesuai kebutuhan.

Undang-Undang Nomor 11 Tahun 2010 tentang Cagar Budaya mengamanatkan bahwa cagar budaya atau objek yang diduga cagar budaya, agar dilindungi keberadaannya. Berdasarkan alasan itu, keberadaan SDA peralatan tambang minyak dan infrastrukturnya harus dilindungi. Asas yang dianut undangundang tersebut adalah pelestarian yang berlatar belakang pemanfaatan untuk sebesarbesarnya bagi kemakmuran rakyat. Jika konsep ini yang harus dipegang maka pengelolaan SDA di Sangasanga juga harus bermanfaat untuk kemakmuran rakyat.

Pada umumnya pemikiran pelestarian dituangkan dalam kajian dan penelitian yang dimaksudkan untuk dapat menjadi pedoman dalam aksi pelestarian, misalnya terhadap bangunan Gereja Kwitang, Jakarta (Dini, 2012), dan model pelestarian dan pemanfaatan situs Kotagede (Muttaqin, 2014). Memperhatikan kajian yang ada, unsur masyarakat belum banyak dibahas meskipun undang-undang mengamanatkan pemanfaatan untuk kemakmuran rakyat. Mengacu pada undang-undang, unsur masyarakat merupakan bagian yang penting untuk dikembangkan, misalnya industri pariwisatanya, agar bisa mensejahterakan.

Dalam pelestarian tinggalan purbakala di Sangasanga yang berupa peralatan tambang dan infrastrukturnya, diperlukan strategi yang tepat. Menurut Undang-Undang Nomor 11 Tahun 2010 tentang Cagar Budaya, kata pelestarian didalamnya antara lain berupa kegiatan atau aktivitas pemanfaatan. Berdasarkan uraian itu, maka permasalahan dalam kajian ini yaitu: 1) Bagaimana cara/bentuk pemanfaatan yang dilakukan oleh masyarakat, sekaligus bermanfaat dalam pelestarian tinggalan arkeologi?; 2) Bagaimana cara/model pemanfaatan yang dapat memberi nilai tambah bagi masyarakat, sekaligus bermanfaat dalam pelestarian tinggalan arkeologi?; 3) Bagaimana mengimplementasikan kegiatan pemanfaatan yang tidak terpisahkan dari kegiatan pelestarian, dapat menjadi kebiasaan dalam kehidupan masyarakat?; 4) Bagaimana strategi pemanfaatan yang tepat dan sekaligus dapat melestarian peninggalan arkeologi kolonial di Sangasanga?

Mengacu pada permasalahan, tujuan penelitian ini dimaksudkan untuk mengkaji: 1) kegiatan pemanfaatan SDA oleh masyarakat yang memberi manfaat pelestarian; 2) kegiatan pemanfaatan SDA yang memberi nilai tambah bagi masyarakat, sekaligus kegiatan tersebut bersifat melestarikan; 3) pelaksanaan kegiatan pemanfaatan yang menjadi bagian dari kegiatan pelestarian, yang dalam operasionalnya menjadi kebiasaan yang dilakukan atau menjadi perilaku masyarakat; dan 4) strategi pemanfaatan yang tepat yang dapat melestarikan peninggalan arkeologi kolonial di Sangasanga. 


\section{KAJIAN LITERATUR}

\section{Alat Tambang Minyak dari Masa Kolonial}

Alat pertambangan pada masa kolonial, terutama untuk pengangkatan minyak dari dalam perut bumi ke permukaan tanah, umumnya berupa pompa angguk (sucker rod pump). Teknologi pada masa awal pertambangan minyak memang lebih banyak menggunakan peralatan ini. Alasannya, pompa angguk merupakan peralatan yang sederhana dan paling mudah dibuat. Prinsip kerja alat ini adalah mengubah gerak putar menjadi gerak naik-turun, sehingga pompa bisa bekerja menaikkan minyak bumi dari dalam sumur ke permukaan tanah.

Dengan peralatan yang sederhana tersebut, biaya produksinya murah dan efisiensinya mencapai 82\% (Arini dkk., 2015). Karena alasan tersebut, pertambangan minyak di Sangasanga yang dilakukan oleh pihak kolonial Belanda, juga menggunakan pompa angguk. Bukti pompa angguk tertua yang sekarang sudah tidak berfungsi, ada di halaman perumahaan Sepuluhsepuluh. Roda pemutar untuk menggerakkan pompa angguk masih menggunakan kayu ulin. Peralatan yang sama dengan ukuran yang lebih kecil juga masih dapat kita lihat di Kelurahan Sarijaya, di tepi Sungai Sangasanga.

\section{Infrastruktur dan Pelestariannya}

Pembahasan infrastruktur dalam subbab ini meliputi infrastruktur pertambangan dan kota. Dalam Kamus Besar Bahasa Indonesia (1995), infrastruktur dimaknai sebagai prasarana, yaitu segala sesuatu yang merupakan penunjang terselenggaranya suatu proses (misalnya pertambangan, berfungsinya kota dll). Sebagai prasarana, di sisi lain terdapat juga sarana utama sebagai peralatan pokok terselenggaranya suatu kegiatan. Dengan demikian, infrastruktur pertambangan minyak wujudnya dapat berupa berbagai sarana yang fungsinya menunjang terselenggaranya kegiatan penambangan minyak. Semua itu diadakan sebagai upaya mendukung berfungsinya sarana utama, kegiatan penambangan minyak. Pengertian tersebut menekankan bahwa tinggalan arkeologi yang berkaitan dengan pertambangan minyak dan infrastrukturnya, merupakan objek dalam kajian ini.

Memperhatikan keberadaan peralatan dan infrastruktur pertambangan minyak masa kolonial Belanda di Kota Kecamatan Sangasanga sekarang ini, terdapat dua hal yang berbeda dalam pembentukkannya, tetapi berada dalam konteks ruang dan waktu masyarakat sekarang. Pertama, peralatan dan infrastruktur pertambangan dibangun pada masa kolonial Belanda dan keberadaannya untuk mendukung kegiatan penambangan minyak. Pembangunan infrastruktur saat itu hanya dimaksudkan untuk kantor, perumahan para pekerja tambang, jalur transportasi barang dan kebutuhan hidup, rumah sakit, serta kawasan pengolahan air agar layak konsumsi. Bahkan Wasita, dkk. (2012) menyebutkan bahwa masyarakat yang bukan karyawan tambang hanya boleh tinggal di seberang (kiri) Sungai Sangasanga.

Kedua, pemisahan ini tidak menunjukkan fungsinya sebagai kota, karena tidak terjadi pengorganisasian yang melahirkan hirarkhi dengan wilayah pedalaman di sekitarnya. Kota Kecamatan Sangasanga terbentuk karena perkembangan kemudian. Fungsinya sekarang sebagai tempat bermukim, menjadikan masyarakatnya berinteraksi dengan tinggalan purbakala dari masa kolonial, misalnya bangunan infrastruktur pertambangan masih digunakan untuk kantor dan sebagian untuk tempat tinggal.

Bangunan bekas gedung kantor BPM, sekarang digunakan sebagai kantor PT. Pertamina UBEP (gambar 1). Perumahan Sepuluh-sepuluh sekarang dihuni para karyawan Pertamina, terutama dari kalangan kelas atas. Bengkel juga masih berfungsi untuk perbaikan peralatan tambang. Sementara itu, barak, tangsi dan komplak, penggunanya adalah masyarakat umum, bukan karyawan Pertamina. Mereka berstatus sebagai peminjam dari Pertamina, sebagai pemegang konsesi. Gedung Rumah sakit masih berfungsi. Pelabuhan dulu ada 9 lokasi, sekarang tinggal dua yang 
berfungsi. Satu untuk pelabuhan umum, dan satu lagi untuk Pertamina. Fasilitas olah raga yang masih berfungsi adalah lapangan sepak bola dan tenis. Gedung pembangkit listrik masih berfungsi, yaitu memasok listrik untuk kegiatan penambangan, kantor Pertamina dan perumahan sepuluh-sepuluh. Lokasi penampungan minyak, ada yang masih berfungsi dan ada juga yang sudah tidak digunakan.

Dengan demikian, infrastruktur pertambangan tersebut dalam konteks sekarang juga menjadi bagian dari infrastruktur Kota Kecamatan Sangasanga. Dalam pembahasan tinggalan kepurbakalaan, objek yang berupa infrastruktur pertambangan (gambar 2), sekarang menjadi bagian dari infrastruktur Kota Kecamatan Sangasanga disebut sebagai SDA.
SDA di Sangasanga berada dalam konteks sistem kehidupan masyarakat. Keberadaannya di tengah-tengah kehidupan masyarakat membawa konsekuensi untuk dimanfaatkan sekaligus dilestarikan.

Berdasarkan kenyataan tersebut, program pelestarian dan pemanfaatan SDA merupakan hal yang mendesak untuk dilakukan. Sementara itu, penelitian tentang pelestarian dan pemanfaatan bangunan purbakala dengan melibatkan masyarakatnya, belum banyak dilakukan. Widyawati dan Syahbana (2013) yang mengkaji keseriusan Pemerintah Kota Semarang dalam pelestarian kawasan kota lama, menghasilkan pengetahuan bahwa terdapat keseriusan dalam perlindungan kawasan cagar budaya yang ditandai dengan pendataan dan

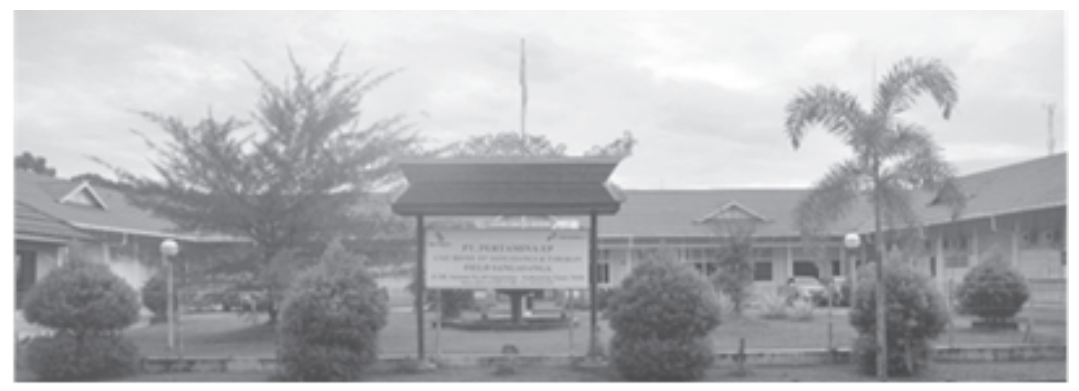

Gambar 1 Bekas kantor BPM dan sekarang menjadi kantor Pertamina UBEP (sumber: Dokumentasi Balai Arkeologi Banjarmasin)

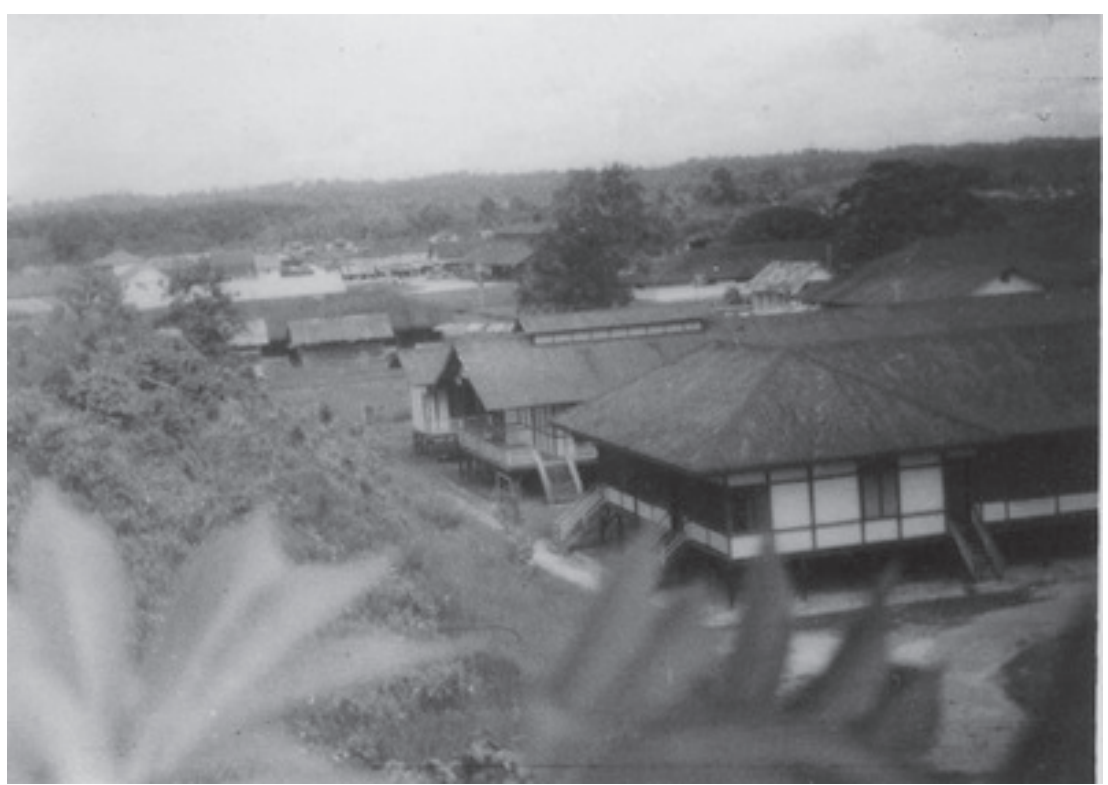

Gambar 2 Infrastruktur pertambangan tahun 1950-an berupa Pesanggrahan Bataafse Petroleum Maatschappij di Sangasanga (sumber: KITLV) 
penetapan cagar budaya, kemudian juga dilakukan perlindungan hukum dan penertiban terhadap pelanggaran yang terjadi. Kegiatan pengembangan juga dinilai cukup serius yang dibuktikan dengan adanya sosialisasi dan promosi wisata. Keseriuasan juga ditunjukkan dalam kegiatan pemanfaatan kawasan cagar budaya dengan cara mempertahankan keaslian, namun tetap memberi peluang kepada masyarakat untuk melakukan perubahan fungsi bangunan, misalnya bekas gudang dan sekarang dimanfaatkan menjadi Art Gallery.

Gagasan yang disampaikan oleh dua peneliti di atas cukup lengkap, yaitu meliputi pelestarian, pengembangan dan pemanfaatan oleh pemerintah. Berbeda dengan gagasan di atas, Primadani, Larasati, dan Subowo (2013) mengajukan gagasan pelestarian dan pengembangan kota yang dikaitkan dengan pembangunan. Gagasan para peneliti tersebut diimplementasikan dengan mendeskripsikan faktor-faktor penghambat dan pendorong kegiatan pelestarian dan pengembangan kawasan kota lama. Hasilnya, pelestarian dapat diraih dengan cara melakukan pembangunan fisik maupun non fisik guna mendukung pengembangan wisata budaya untuk menghidupkan kembali Kota Lama Semarang sesuai dengan peraturan daerah yang berlaku, dan juga sebagai upaya mengkonservasi bangunan cagar budaya. Dalam konteks ini, menurut I Wayan Suweda (2011), yang tidak kalah penting guna melaksanakan pembangunan untuk kegiatan pelestarian kota lama adalah konsep tata ruangnya.

Kajian-kajian di atas menunjukkan bahwa pengelolaan kota masih difokuskan kepada pihak-pihak yang memiliki kekuasaan atau paling tidak dekat dengan kekuasaan. Kecenderungannya, masyarakat tidak dilibatkan dalam pengelolaan. Oleh karena itu, penelitian ini akan difokuskan pada pengelolaan SDA di Kota Kecamatan Sangasanga yang meliputi pelestarian dan pemanfaatan dengan melibatkan secara aktif masyarakat yang tinggal dan berinteraksi dengan SDA. Dengan pelibatan tersebut diharapkan masyarakat tidak hanya didorong untuk melakukan pelestarian tetapi juga diupayakan tercipta habit untuk senantiasa melestarikan dan mendapatkan nilai tambah atas upaya pelestarian yang dilakukan.

\section{Strategi Pelestarian dan Pemanfaatan}

SDA perlu dilestarikan, itu merupakan amanat Undang-Undang Nomor 11 tahun 2010 tentang Cagar Budaya. Kenyataannya, keberadaan undang-undang tersebut tidak secara otomatis memberi dampak pada terlestarikannya cagar budaya di lingkungan kita. Terjadinya proses hingga lestarinya cagar budaya harus diusahakan, dan jika tidak, pasti akan terjadi kerusakan. Hasil penelitian tentang penyebab kerusakan cagar budaya di Yogyakarta yang dilakukan Harjiyani dan Raharja (2012) disebutkan bahwa kerusakan tersebut disebabkan oleh fakor alam dan manusia. Faktor alam terjadi karena gempa, pelapukan dan lainlain, sedangkan faktor manusia terjadi karena dilakukan goresan, coretan, pemugaran tanpa ijin sehingga terjadi perubahan bentuk bahkan dibongkar dan kemudian diganti dengan bangunan baru, sehingga bangunan purbakala menjadi musnah. Oleh karena itu ada keinginan untuk memiliki aturan yang lebih spesifik dan detail dalam pelaksanaan pelestarian cagar budaya. Panggabean (2014) menghadirkan contoh pengelolaan SDA yang dilakukan Pemerintah Kota Semarang yang berinisiatif membuat Peraturan Daerah tentang Cagar Budaya.

Implementasi undang-undang tersebut ditujukan kepada cagar budaya, dan bukan SDA. Dalam konteks ini, banyak SDA di Sangasanga yang belum ditetapkan menjadi cagar budaya, padahal jika memperhatikan hasil penelitian Susanto (2005), Tim Peneliti, (2008:), dan Wasita dkk., (2012), diketahui bahwa terdapat situs dan kawasan di Sangasanga yang memiliki SDA yang layak ditetapkan menjadi cagar budaya. Faktanya, hingga sekarang belum ada penetapan, akibat yang bisa disaksikan adalah SDA di Sangasanga tidak terurus dengan baik. 
Adanya kasus kerusakan SDA di berbagai tempat dan tidak terurusnya SDA di Sangasanga, harus ditanggapi dengan upaya pelestarian. Langkah awal yang perlu ditempuh adalah mencagarbudayakan SDA pertambangan minyak dan seluruh prasarananya. Hal itu dilakukan agar kegiatan pelestarian yang direncanakan memiliki landasan hukum, terutama dalam hal pendanaan dan aturan-aturan yang mengikatnya. Oleh karena itu, situs dan kawasan yang telah ditetapkan sebagai cagar budaya akan memiliki konsekuensi, baik bagi pemerintah daerah maupun masyarakat di sekitarnya. Konsekuensi tersebut adalah adanya kewajiban bagi pemerintah setempat untuk melakukan pelestarian sedangkan bagi masyarakat tidak bisa lagi melakukan perubahan maupun pembongkaran dan pemindahan.

Keberadaan SDA dalam masyarakat Sangasanga, menjadikan sumber daya tersebut berada dalam konteks sistem kehidupan masyarakat. Pengelolaan yang paling efektif terhadap SDA yang berada dalam konteks sistem, menurut Widiyati dan Wasino (2011) serta Purnawibowo (2014) adalah dengan cara melibatkan masyarakat untuk turut mengambil bagian dalam kegiatan pengelolaan, begitu pula menurut Jaya (2012) dan Wiratmoko (2012,) bahwa memberi peluang kepada mereka agar bisa mendapatkan keuntungan atas dilaksanakannya pengelolaan tersebut. Menurut kedua peneliti yang disebut terakhir, pengembangan sektor pariwisata juga akan meningkatkan sektor ekonomi dan disinilah diharapkan masyarakat dapat mengambil peluang usaha agar memperoleh keuntungan.

Dalam konteks ini, pelestarian berbasis pemanfaatan dapat dilakukan dengan mengangkat situs dan kawasan di Sangasanga menjadi objek pariwisata warisan budaya. Kegiatan pariwisata diciptakan dengan memanfaatkan objek arkeologi berupa peralatan dan infrastruktur pertambangan minyak. Pemanfaatan situs dan kawasan dapat dilakukan dengan reuse yaitu penggunaan ulang yang titik beratnya lebih pada penggunaan dan penggunaan tersebut tidak harus sama dengan yang sebelumnya. Pengertian reuse menurut Orbasli, (2008 dalam Suryono, 2012) ialah penggunaan (misalnya bangunan lama) untuk fungsi yang berbeda demi kebergunaan.

Fakta di lapangan menunjukkan bahwa, bangunan/infrastruktur dan peralatan tambang di Sangasanga, pada umumnya masih difungsikan sejak masa BPM hingga kini. Sebagian difungsikan sama dengan fungsi awalnya dan sebagian lain berfungsi sama tetapi diperuntukkan pada pihak yang berbeda, dan sebagian sudah masuk dalam konteks arkeologi, misalnya kolam renang, penjara, dan gua Jepang, kubu pertahanan, Tugu Pembantaian, pompa angguk Thomassen yang sudah dipindahkan ke kota Sangasanga, pelabuhan raja (sekarang tidak berfungsi), dan Tugu RIS. Secara lengkap lokasi SDA masa kolonial di Sangasanga dapat dilihat pada Gambar 3.

Berdasarkan pada pengertian pemanfaatan seperti tersebut di atas dan realitas penggunaan bangunan/infrastruktur dan peralatan tambang di Sangasanga, ada yang dapat disebut reuse tetapi ada juga yang disebut penggunaan berlanjut. Dalam hal ini bangunan yang dikategorikan sebagai reuse adalah bangunan yang tidak lagi difungsikan seperti semula, misalnya barak, bangsal, tangsi, gedung Sandisa, dan komplak. Dalam rangka menunjang program pariwisata yang diusulkan, masyarakat penghuni bangsal, barak, dan komplak diberi pelatihan untuk memproduksi dan menjual hasil kerajinan khas Sangasanga atau pun Kalimantan Timur. Misalnya perisai sebagai hiasan, kain ulap doyo dengan bahan serat kayu, bening aban (sejenis tas untuk menggendong bayi), manikmanik, sumpit, Mandau dan lain-lain. Dengan demkian, ada dua keuntungan yang bisa diraih dari reuse, yaitu dilibatkannya masyarakat untuk turut merawat serta melestarikan tinggalan arkeologi berupa bangunan yang dihuni dan mendapatkan keuntungan dari jual beli.

Infrastruktur dan peralatan tambang yang penggunaannya berlanjut sampai sekarang, dinamakan living monument. Menurut I Nyoman 


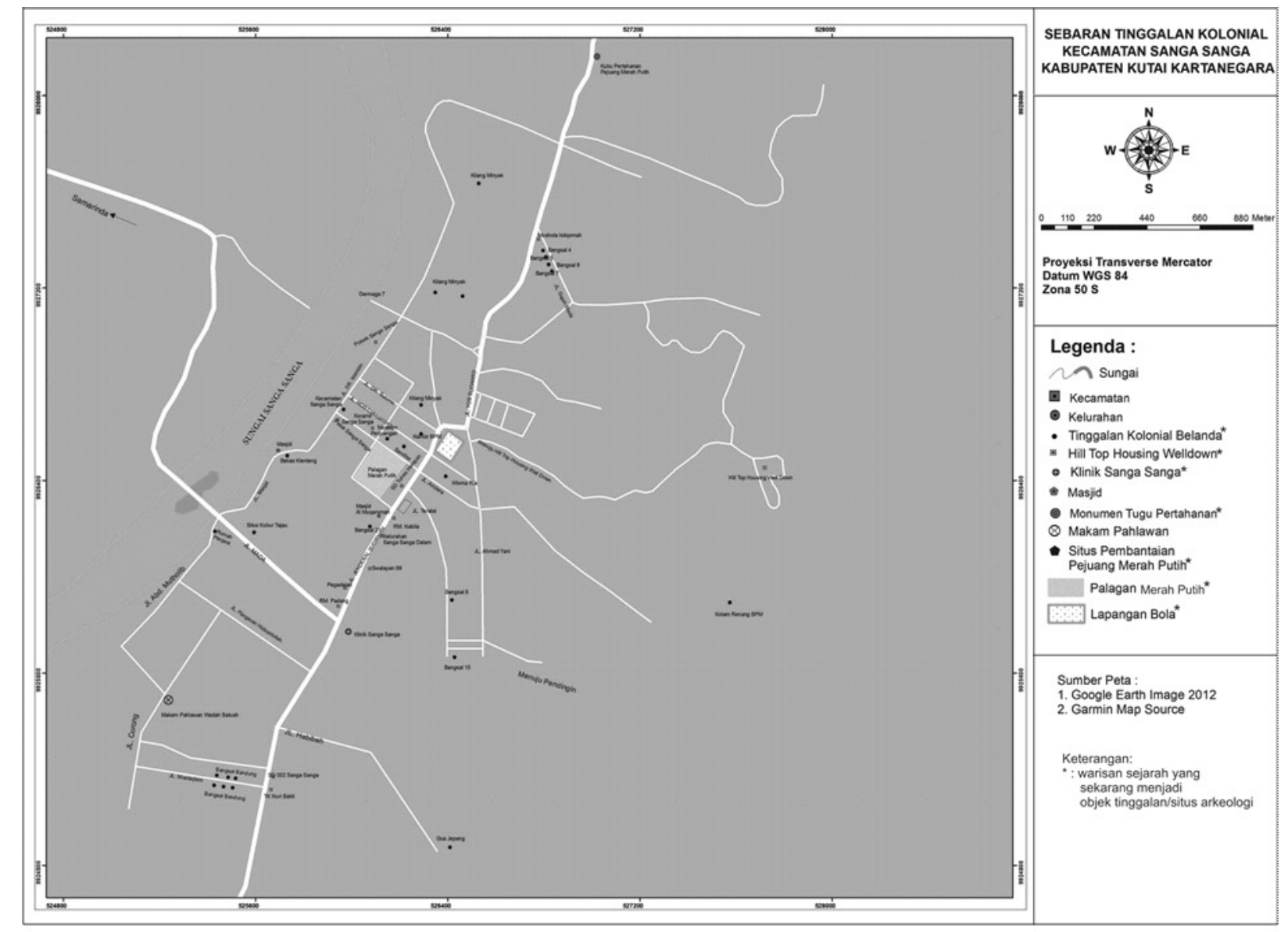

Gambar 3 Sebaran tinggalan arkeologi di antara fasilitas umum dan ruang publik di Sangasanga (sumber, Wasita dkk., 2012)

Wardi (2008) living monument dapat berupa benda atau monumen yang mempunyai hubungan erat dengan masyarakat kontemporer selaku pendukung budaya tersebut dan masih difungsikan dalam sistem kehidupan sosiokultural. Hubungan tersebut menyangkut sejarah, sosial-ekonomi, politik, dan konteks kultural. Living monument mencerminkan kelekatan hubungan dan dinamika kehidupan sosial dan budaya secara diakronis dari masa ke masa dengan segala modifikasinya sebagai mekanisme adaptasi terhadap perubahan yang ditimbulkan dari dalam (internal) maupun luar (eksternal).

Tindakan menghadirkan kembali bangunan/ infrastruktur dan peralatan tambang sebagai living monument dan sebagian di-reuse merupakan tindakan untuk tujuan pelestarian. Lebih dari itu juga dimaksudkan untuk meng- hadirkan nostalgia rangkaian sejarah perkembangan Sangasanga. Diharapkan nostalgia itu juga akan menjadi daya tarik bagi para turis untuk datang dan tinggal sementara guna merasakan langsung derap kehidupan Sangasanga yang bersejarah. Dengan demikian, upaya itu juga diharapkan berdampak pada kegiatan ekonomi masyarakat.

Nostalgia ini akan menjadi nilai lebih bagi Sangasanga karena merupakan nilai sejarah yang tidak dimiliki daerah lain. Kenangan ini akan menjadi daya tarik bagi siapa saja untuk turut merasakan. Suasana nostalgia yang disertai dengan keberadaan bangsal-bangsal yang kembali menggeliat bersama aktivitas kegiatan pertambangan, akan menjadi pemandangan yang menarik. Aktivitas masuk, istirahat dan pulang bagi para pekerja tambang dan perkantoran yang hingga kini masih ditandai dengan bunyi 
soling dari menara pengawas, seperti pada masa kolonial, merupakan pemandangan yang eksotik. Apalagi, sirine itu ditempatkan di menara pengawas yang berada di puncak bukit, menjadikan suaranya menyebar ke segala penjuru pusat kota Sangasanga, sehingga mereka yang menghuni bangsal B 21, tangsi dekat taman Sangasanga, rumah sakit, perkantoran utama, perumahan Sepuluh-sepuluh, perumahan seberang Sepuluh-sepuluh, Bangsal Blok C di Jalan Jenderal Sudirman, dapat mendengar dengan jelas.

Tampak jelas ketika sirine itu berbunyi di pagi hari, menandakan mobil penjemputan karyawan mulai bergerak, kesibukan di jalanjalan menjadi semakin padat. Beberapa menit kemudian, para pekerja tambang dan perkantoran yang menunggu jemputan di ujung gang, misalnya di sekitar pasar Sangasanga, sudah mulai berkurang karena satu per satu sudah didatangi mobil penjemputnya masingmasing untuk menuju ke tempat kerjanya. Pemandangan yang demikian akan kita temui di seputaran pusat kota Sangasanga, setiap pagi dan sore. Sementara itu di siang hari, lengkingan bunyi soling akan menandakan jam istirahat. Dalam kesempatan itu kita bisa melihat para pegawai kantor berhamburan keluar gedung. Biasanya, arah langkah keluar para karyawan tersebut menuju ke rumah makan yang ada di sekitar perkantoran.

Guna mewujudkan reuse bangunan yang demikian, sudah semestinya bangsal-bangsal dipugar terlebih dahulu dan menjadi bangunan yang layak huni. Namun demikian, pemugaran tersebut harus mengedepankan hasil yang mempertahankan keaslian. Untuk mendukung kenyamanan bagi penghuni perlu ditambah dengan beberapa fasilitas. Namun, hal tersebut jangan sampai mengganggu keasliannya. Selanjutnya, agar bangunan kelihatan nyaman dipandang, keasrian lingkungan harus terpelihara. Semua itu akan menjadi daya tarik bagi siapa saja untuk mencoba merasakan sensasi nostalgia yang nyaman dan asri, dengan cara hadir di tempat itu atau pun tinggal untuk beberapa lama di sana.

Sementara itu, reuse dengan tujuan untuk ekonomi sudah dilakukan terhadap bekas gedung kesenian Sandisa, yang disewakan untuk gedung pertemuan dan pesta pernikahan, Wisma Ria untuk gedung petemuan, dan diusulkan ditambah dengan bangsal, barak, tangsi, dan komplak, yaitu untuk tinggal dan juga kegiatan ekonomi, serta villa untuk penginapan. Reuse dan pemanfaatan SDA dimaksudkan untuk mendukung kegiatan pariwisata. Dalam hal ini, pengemasannya dikaitkan dengan potensi dan kegiatan-kegiatan yang ada dan dilakukan di Sangasanga maupun di wilayah sekitarnya. Sangasanga merupakan kota perjuangan yang diperingati setiap tanggal 27 Januari. Potensi ini merupakan modal untuk pengembangan pariwisata. Potensi yang lain adalah sejarah perjuangan beserta bukti materialnya yang diwacanakan untuk dijadikan objek wisata.

Objek wisata sejarah yang dimaksudkan antara lain adalah Museum Perjuangan Merah Putih, Tugu Habib Abdul Mutholib, Monumen batu kedaulatan Republik Indonesia Serikat (RIS), Tugu Kerukunan Umat Beragama, Tugu Monumen Perjuangan Merah Putih, Tugu Pembantaian, Taman Makam Pahlawan Wadah Batuah, dan bekas Penjara Kolonial Belanda. Objek arkeologi lain yang dapat dijadikan sebagai tujuan wisata adalah kubur tradisional dengan wadah tajau. Objek wisata yang tidak terkait dengan sejarah, misalnya adalah pemandian air panas. Semua itu harus dijadikan paket untuk dipromosikan kepada khalayak. Di samping itu, ada event erau, upacara tinjak tanah (menginjak tanah) bagi putra raja dan kerabatnya yang berusia lima tahun, yang merupakan upacara sakral yang dilaksanakan oleh Kesultanan Kutai Kartanegara, di Tenggarong. Sekarang ini, erau telah menjadi kegiatan multi event, kolaborasi antara tradisi dengan atmosfir kekinian yang harmonis. Berkaitan dengan itu, wisata warisan budaya di Sangasanga juga perlu diperkenalkan dengan 
cara promosi dalam satu paket wisata, erau dan wisata warisan budaya di Sangasanga.

Gagasan pemanfaatan SDA berupa peralatan tambang juga dapat ditujukan kepada Pertamina UBEP, terutama pada divisi pengembangan sumberdaya manusia. Beberapa lokasi pengeboran minyak yang mulai berkurang produksinya dan sudah tidak mungkin ditingkatkan lagi, dapat dimanfaatkan untuk kegiatan pelatihan/praktek, terutama bagi calon-calon kayawan. Pengembangan ini akan terus memberikan nilai tambah sekalipun potensi minyaknya sudah sangat berkurang. Nilai tambah tersebut adalah diperolehnya tenaga kerja yang memadai dan adanya pemasukan dari jasa pendidikan. Pemanfaatan yang demikian ini selain tetap memberikan hasil, juga akan bermanfaat untuk perawatan peralatan pertambangan lama, yang sekaligus merupakan kegiatan pelestarian SDA.

\section{Pengembangan Wisata Warisan Budaya}

Menurut Richard W. Butler (2011 dalam Hayati, 2014), pengembangan wisata warisan budaya harus mempertimbangkan attraction, accessibility, amenities, available packages, activities, ancillary service yang ditambah dengan faktor promosi wisata. Berdasarkan cara tersebut, pengembangan wisata warisan budaya harus memperhatikan objek wisata dalam kaitannya dengan daya tariknya, kemudahan dalam menuju lokasi, sarana penunjang kepariwisataan, ketersediaan paket wisata, aktivitas yang bisa ditawarkan untuk wisatawan di lokasi wisata, pelayanan pendukung, dan promosi yang dilakukan.

Berdasarkan kriteria tersebut, selanjutnya Hayati (2014) menilai apakah suatu objek wisata memenuhi kriteria atau tidak. Sejauh mana kriteria tersebut berfungsi sehingga signifikan dengan jumlah pengunjung. Hal itu akan menjadi standar penilaian objek wisata dalam rancangan pengembangannya. Misalnya, kurang atau belum lengkapnya kriteria seperti tersebut di atas, akan menjadikan status objek wisata masih dalam keadaan eksplorasi. Namun, jika sudah lengkap tetapi belum mendatangkan jumlah wisatawan banyak, maka disebut berstatus pengembangan.

\section{Hambatan dan Tantangan}

Upaya mengangkat SDA menjadi objek dan tujuan wisata, juga menjadi perbincangan sebagian ahli karena adanya kekhawatiran akan dampak negatif dari kegiatan tersebut. Alasan pihak yang melakukan penentangan terhadap dimasukkannya atraksi budaya ke dalam sistem ekonomi atau komersialisasi tradisi budaya karena disinyalir akan berdampak kurang baik bagi tradisi itu sendiri. Oleh karena itu, Nuryanti dan Suwarno (2008) menyebutkan bahwa pengembangan pariwisata juga harus mendukung upaya pelestarian objek itu sendiri. Hal ini juga berarti bahwa pengembangannya tidak boleh mengurangi atau menghilangkan nilai dari objek yang menjadi daya tarik bagi wisatawan.

Saleh (2004) berpendapat bahwa pelestarian dan pengembangan pariwisata memiliki paradigma, sasaran, dan sudut pandang yang berbeda. Oleh karena itu, pemanfaatan warisan budaya dan peninggalan sejarah untuk kepentingan pengembangan pariwisata dapat mengganggu kelestarian warisan budaya, baik fisik maupun nonfisik. Berkaitan dengan kekhawatiran itu, strategi yang ditempuh Pemerintah Daerah Istimewa Yogyakarta untuk mencapai keselarasan antara pelestarian dan pengembangan pariwisata Kotagede, tertuang dalam Rencana Strategis Dinas Kebudayaan dan Pariwisata, penegakan hukum, dan sosialisasi untuk meningkatkan kesadaran hukum terkait dengan keharusan untuk melestarikan cagar budaya.

Mengantisipasi hal yang sama, dalam penanganan SDA di Sangasanga untuk kepentingan pariwisata, perlu dilakukan rencana strategis. Rencana strategis tersebut tidak hanya mengedepankan jumlah kunjungan, tetapi juga upaya untuk terciptanya kelestarian SDA. Idealnya, terciptanya kelestarian tidak hanya dari perawatan yang dilakukan pemerintah, tetapi juga pihak penghuni barak, bangsal, 
komplak, perumahan, dan pengguna peralatan tambang juga turut melestarikan. Tuntutan untuk itu bisa disandarkan kepada para penghuni dan pengguna peralatan tambang, karena mereka memang memiliki tanggung jawab itu, dalam kaitannya sebagai pengguna SDA.

Pada akhirnya, tanggung jawab yang demikian ini yang harus terus dipertahankan, agar masyarakat pengguna turut ambil bagian dalam pelestarian. Permintaan tersebut bukanlah suatu hal yang berlebihan karena mereka juga diberi kesempatan untuk memanfaatkan, bahkan juga mengambil keuntungan atas penggunaan yang dilakukan. Keuntungan yang bisa diperoleh dari para pengguna inilah yang diharapkan akan menjadi penggerak kesadaran untuk terus melibatkan diri dalam pelestarian SDA, terutama pada bangunan yang mereka manfaatkan.

\section{METODE}

Metode pengumpulan data dalam penelitian ini dilakukan melalui pengamatan/observasi, wawancara, dan studi pustaka. Pengumpulan data melalui pengamatan dimaksudkan untuk mendapatkan data-data visual beserta pemikiran logisnya (Rahardjo, 2011). Misalnya, pengamatan terhadap perawatan dan perubahan-perubahan yang terjadi pada bangunan purbakala di Sangasanga. Wawancara dimaksudkan untuk menggali (Endraswara, 2006), merekonstruksi, dan mengungkap proyeksi pemikiran informan (Lincolndan Guba, 1985, dalam Moloeng, 2014). Informan adalah orang-orang yang dianggap mengerti mengenai tinggalan bangunan purbakala di Sangasanga.

Wawancara juga dimaksudkan untuk mengetahui sesuai tidaknya antara pemikiran dan tindakan yang telah dilakukan oleh informan terhadap tinggalan purbakala atau SDA yang diperoleh dari pengamatan. Kepastian sinkron tidaknya pemahaman dan tindakan dimaksudkan untuk mengungkap latar belakang informan yang secara gagasan memahami prinsip-prinsip pemugaran cagar budaya, tetapi dalam praktik melakukan tindakan yang menyalahi prinsip tersebut. Pemahaman mengenai sebab dilakukannya penyimpangan terhadap prinsip pemugaran oleh informan akan menjadi bekal dalam mengkaji pemasalahan sehingga diperoleh rekomendasi yang tepat untuk perawatan dan pemugaran yang dilakukan penghuni.

Sebagai upaya untuk fokus pada permasalahan, dalam praktiknya wawancara dipandu dengan pedoman (Rachmawati, 2007) pertanyaan yang meliputi aspek-aspek yang tekait dengan permasalahan. Pertanyaan tersebut misalnya mengenai sudah berapa lama tinggal di barak, komplak dan tangsi, minta ijin tinggalnya kepada siapa, apa pesan pihak yang memberi ijin, apa saja yang dilakukan pemberi izin selama yang bersangkutan tinggal di rumah itu, apa saja yang pernah dilakukan penghuni terhadap rumah tinggal itu, dll.

Guna mendukung pengumpulan data dari lapangan, dilakukan studi pustaka baik pada pra maupun pasca kegiatan lapangan. Hal ini dilakukan sebagai langkah untuk memperkuat data dan analisis tentang pandangan pemangku kepentingan (stakeholders) serta penghuni rumah/bangunan kolonial dan implementasinya dalam pemanfaatan dan pelestarian bangunan purbakala yang mereka tempati.

Analisis data dilakukan dengan metode deskriptif yang dilakukan dengan memberikan gambaran secara lengkap dan utuh terkait dengan perawatan dan pemugaran bangunan purbakala yang dilakukan oleh penghuninya dan latar belakang dilakukannya hal tersebut. Karena penghuni bangunan purbakala hanya meminjam, berarti ada pihak lain yang berhak menegur. Oleh karena itu, dalam analisis juga digambarkan strategi penghuni dalam mengantisipasi klaim pihak pemilik/penguasa, agar penghuni tidak dianggap melanggar batasan yang telah diberikan. Berkaitan dengan ini, sejak di lapangan telah dilakukan pengelolaan data seperti halnya yang disarankan oleh Gunamantha dan Susila (2015) yang meliputi perangkuman, pengkodean, perumusan tema, pengelompokan, dan penyajian. Perangukuman merupakan penataan data dalam bentuk ringkas, dengan cara memberikan kode setiap jenis data, agar dapat 
dirumuskan tema datanya, sehingga dapat dikelompok-kelompokkan. Semua itu dilakukan untuk mempermudah penyajian dalam bentuk tulisan.

\section{HASIL DAN PEMBAHASAN}

\section{Pemanfaatan yang Bersifat Melestarikan}

Upaya pemanfaatan yang bersifat melestarikan akan berkaitan dengan SDA, strategi pemanfaatan, kelestarian, dan masyarakat yang dalam hal ini termasuk kelembagaan, misalnya Pertamina UBEP, Yayasan Pendidikan dan Kepolisian sebagai pengguna bangunan. Kaitan masyarakat terhadap faktor-faktor tersebut terletak pada keberadaannya sebagai pihak yang diharapkan akan mendapatkan keuntungan atas pemanfaatan yang dilakukan. Dengan posisi ini, diharapkan akan mendorong pengguna untuk turut aktif melestarikan objek (bangunan) purbakala yang telah memberikan manfaat dan keuntungan.

Tampaknya, desain pemanfaatan yang bersifat melestarikan seperti itu akan dapat terlaksana bila semua berada dalam tataran ideal. Semua berlangsung seperti yang diharapkan, dan manfaat yang ditawarkan benar-benar dapat dirasakan. Contoh, pemanfaatan gedung-gedung lama di Kota Semarang, yaitu bekas kantor NV Cultuur Maatschappij der Vorstenlandeen, sekarang sebagai kantor PT. Perkebunan XV, Gereja Blenduk dan Kantor Advokat, hingga sekarang masih difungsikan untuk hal yang sama, gedung kantor NV Bouw Maatschappy, sekarang digunakan oleh PT Pelni, gedung kantor dagang Oei Tiong Ham Cancern, sekarang menjadi perkantoran (antara lain PT. Rajawali Nusindo), gedung kantor 'de Spaar Bank' sekarang menjadi kantor Bank Niaga, gedung 'Escompto Bank' sekarang sebagai kantor Bank Dagang Negara (Kadarwati, 2008).

Pemanfaatan ideal bisa diwujudkan jika pelaksanaannya berdasarkan Undang-undang Nomor 11 tahun 2010 tentang Cagar Budaya. Dalam kaitannya sebagai warisan budaya, institusi yang memiliki kaitan dengan pelestarian dan pemanfaatan SDA adalah Balai Arkeologi,
Balai Pelestarian Cagar Budaya dan Dinas yang mengurusi kebudayaan. Ketiga institusi ini harus melibatkan diri secara aktif agar pemanfaatan yang bersifat melestarikan seperti yang digagas di atas bisa terwujud.

Harapan agar ketiga institusi tersebut terlibat aktif dalam program pelestarian merupakan tuntutan atas realitas di lapangan. Faktanya, sekarang ini sebagian SDA di Sangasanga sudah dalam posisi dimanfaatkan oleh masyarakat, lembaga pemerintah, dan swasta. Namun, yang terjadi justru tidak sepenuhnya pemanfaatan yang dilakukan berdampak pada kegiatan pelestarian. Ada sebagian barak yang tidak terawat akibat penghuninya merasa tidak mampu secara finansial untuk melakukan perawatan. Di sisi lain, ada yang melakukan perawatan tetapi pelaksanaannya menyalahi prinsip-prinsip pemugaran terhadap bangunan purbakala.

Jika kondisi ini dibiarkan, akan terjadi kerusakan yang semakin parah dan juga perubahan bentuk bangunan, sehingga mengurangi keaslian warisan budaya. Guna mengantisipasi hal itu, perlu dilakukan penelitian (oleh Balai Arkeologi), dan dua istitusi yang lain (Balai Peleastaraian dan Dinas), melakukan koordinasi dengan pemilik (Negara), pemegang konsesi (Pertamina UBEP), dan peminjam (masyarakat, yayasan, dan Polsek setempat) dan mencagarbudayakan SDA, sejauh itu semua memungkinkan dan memenuhi persyaratan.

Penelitian dimaksudkan untuk menggali informasi SDA dan juga menemukan strategi yang tepat dalam kegiatan pemanfatan dan pelestarian. Koordinasi dimaksudkan untuk meletakkan pemahaman yang sama sehingga keputusan yang diambil tidak menimbulkan kerugian pada masing-masing pihak. Sebaliknya, dengan mencagarbudayakan SDA diharapkan akan semakin banyak pihak yang diuntungkan. Misalnya, pemegang konsesi masih diberi peluang untuk terus melanjutkan pemanfaatanya. Hanya saja ada batasan-batasan sehingga yang dilakukan tidak menimbulkan kerusakan SDA. Hal yang sama juga dilakukan kepada peminjam 
untuk terus dapat memanfaatkan sejauh tidak merusak.

Pengawasan pemanfaatan dengan batasbatas tertentu itulah yang perlu dilakukan oleh Balai Pelestarian Cagar Budaya Samarinda dan Dinas Kebudayaan dan Pariwisata Kabupaten Kutai Kartanegara. Dalam hal ini aturan yang digunakan untuk membatasi adalah undangundang. Selanjutnya, agar posisi mereka kuat dalam menerapkan undang-undang, SDA tersebut perlu dicagarbudayakan.

\section{Pemanfaatan yang Memberi Nilai Tambah}

Upaya untuk mewujudkan SDA di Sangasanga memberi bermanfaat sekaligus tetap lestari, adalah dengan cara menjadikan SDA tersebut sebagai objek wisata warisan budaya. Agar SDA menjadi objek wisata yang bermanfaat dan lestari, harus memperhatikan beberapa hal. Hal tersebut adalah potensi objek wisata, pengelolaan, masyarakat Sangasanga itu sendiri, dan wisatawan yang ditargetkan menjadi pengunjung. Pada dasarnya pembicaraan halhal tersebut akan terkait dengan keinginan memanfaatkan SDA yang memiliki nilai tambah dan sekaligus bersifat melestarikan objeknya. Sementara itu, berkaitan dengan target keberhasilan mewujudkan SDA Sangasanga menjadi objek wisata, pengembangannya harus memperhatikan faktor-faktor yang berkaitan dengan daya tarik, objek, dan pengembangan sarana penunjangnya.

Yang dimaksudkan nilai tambah adalah hal baru yang positif yang diperoleh karena penanganan terhadap sesuatu. Misalnya, penanganan SDA untuk objek wisata warisan budaya. Dalam konteks ini, yang dikaitkan dengan upaya untuk mendapatkan nilai tambah adalah SDA, program pariwisata, dan partisipasi masyarakat. SDA yang dikembangkan menjadi objek wisata adalah yang memiliki potensi. Misalnya, daya tarik mengenai sebarang tinggalan arkeologi kolonial di Sangasanga dan informasi kesejarahannya.

Jika digarap dengan baik, potensi SDA tersebut akan menjadi kekuatan yang besar untuk dikembangkan menjadi program pariwisata yang dapat mendatangkan devisa. Penggarapan potensi berkaitan dengan instisuti yang membidanginya, yaitu Dinas Kebudayaan dan Pariwisata dengan dukungan Pemerintah Kabupaten Kutai Kartanegara. Dalam hal ini, program yang dibuat diharapkan melibatkan masyarakat secara aktif agar mereka dapat mengambil peran dan mendapatkan keuntungan dari program tersebut. Upaya tersebut tidak hanya berhenti pada keberhasilan mendatangkan nilai tambah, tetapi sekaligus sebagai upaya pelestarian. Upaya ini sesuai dengan sasaran yang ingin dicapai yaitu yang akan memperoleh nilai tambah adalah masyarakat di sekitar tempat keberadaan SDA. Hal ini berarti sejalan dengan amanat Undang-Undang Nomor 11 tahun 2010 tentang Cagar Budaya yang menyebutkan bahwa pemanfaatan untuk kemakmuran rakyat. Dalam hal ini, nilai tambah diperoleh dari para wisatawan yang membayar jasa dan belanja yang dilakukan.

Agar bisa terwujud yang demikian, langkah yang bisa ditempuh adalah dinas membuat program wisata warisan budaya dengan melibatkan Balai Pelestarian Cagar Budaya dan Balai Arkeologi. Dalam membuat program wisata warisan budaya, harus memperhatikan daya tariknya, kemudahan dalam menuju lokasi, sarana penunjang kepariwisataan, ketersediaan paket wisata, aktivitas yang bisa ditawarkan untuk wisatawan di lokasi wisata, pelayanan pendukung dan promosi. Selanjutnya, Balai Pelestarian Cagar Budaya berperan untuk mengisi program wisata warisan budaya yang melibatkan masyarakat untuk turut melestarikan objek wisatanya. Sementara itu, Balai Arkeologi berperan dalam mengisi content untuk melengkapi informasi sejarah dan nilai penting warisan budaya.

Berkaitan dengan daya tarik, ada tiga macam objek wisata, yaitu alami, budaya, dan event. Menurut Agustina (2012), daya tarik budaya dan event diistilahkan sebagai motivasi kebudayaan, yaitu minat untuk mengunjungi atraksi budaya, objek seni, serta objek sejarah 
dan bukti materialnya. Sementara itu, menurut Undang-Undang Nomor 10 Tahun 2009 tentang Kepariwisataan, terutama pada Bab I, Pasal 1 (5) disebutkan bahwa "Daya Tarik Wisata adalah segala sesuatu yang memiliki keunikan, keindahan, dan nilai yang berupa keanekaragaman kekayaan alam, budaya, dan hasil buatan manusia yang menjadi sasaran atau tujuan kunjungan wisatawan."

Berdasarkan pengertian tersebut, SDA di Sangasanga dapat dijadikan sebagai objek wisata warisan budaya dengan program yang dijalankan oleh dinas setempat. Setelah menyandang status sebagai cagar budaya, Balai Pelestarian Cagar Budaya menindaklanjuti dengan memugar warisan budaya. Selanjutnya, informasi dari Balai Arkeologi yang berupa cerita rangkaian sejarah, nilai penting, keunikan, dan keaslian harus dijaga dan dimengerti oleh masyarakat yang selalu bersentuhan dengan warisan budaya tersebut, untuk turut melestarikannya sekaligus menjadi bekal yang dapat disampaikan kepada wisatawan dan menjadi daya tarik wisata warisan budaya di Sangasanga.

Masyarakat diharapkan berperan dalam pelestarian SDA dengan cara memanfaatkan SDA sekaligus memperoleh keuntungan darinya. Berkaitan dengan itu, langkah strategis bagi Balai Pelestarian Cagar Budaya adalah mengedukasi masyarakat agar mereka selalu turut melestarikan SDA yang sebenarnya juga merupakan salah satu sumber pendapatan finansial mereka. Dalam hal ini, masyarakat yang perlu diedukasi adalah mereka yang terlibat dalam pemanfaatan SDA, baik yang langsung bersentuhan dengan SDA maupun yang tidak. Mereka yang tidak langsung bersentuhan adalah penyedia jasa transportasi, pengusaha rumah makan, pedagang, dan berbagai pengusaha yang salah satu konsumennya adalah wisatawan.

Cara mengedukasi dilakukan dengan memberi informasi kepada mereka tentang sejarah, nilai penting, keunikan, dan keaslian yang harus dijaga. Informasi bisa diberikan dengan cara sosialisasi dan juga memberikan selebaran. Diharapkan bekal pengetahuan itu akan menjadi landasan dalam mempersepsikan warisan budaya untuk selalu dilestarikan karena alasan nilai penting yang dikandungnya, sekaligus sebagai aset yang dapat mendatangkan keuntungan dalam menjalankan profesinya (misal penjual cindera mata, jasa transportasi, dII).

Masih mengenai daya tarik, pihak pemegang konsesi, terutama dari divisi pengembangan sumberdaya manusia, dapat memanfaatkan areal dan peralatan untuk belajar dan praktik pertambangan. Divisi ini dapat menyelenggarakan pelatihan bagi putra-putri yang ingin bekerja di pertambangan minyak. Pelatihan meliputi teori yang dilaksanakan di dalam kelas dan praktik di lapangan. Dalam hal ini praktik bisa menggunakan peralatan yang sudah ada dan sekarang ini berada di lahan dengan sumber minyak yang sudah mulai menipis.

Dengan pengembangan tersebut, akan diperoleh beberapa keuntungan. Pertama, lahan dengan sumur yang sudah menurun tingkat produksinya masih dapat dimanfaatkan untuk mendatangkan keuntungan finansial. Kedua, pemegang konsesi memberi kontribusi dalam hal penyediaan sumber daya manusia yang memadai pada bidang eksplorasi minyak. Ketiga, pemegang konsesi juga berperan dalam melestarikan SDA terutama mengenai peralatan tambang lama dan seluruh lanskap pertambangan yang sudah mulai terbentuk sejak masa kolonial. Keempat, belajar dan praktik di lokasi yang memiliki sejarah pertambangan yang cukup lama juga merupakan daya tarik, yaitu keunggulan dalam pengalaman.

Berkaitan dengan akses kemudahan menuju lokasi wisata Sangasanga, jalan menuju ke semua lokasi sudah tersedia yaitu ada yang sudah beraspal, ada juga yang masih berupa jalan tanah. Melihat potensi yang seperti ini, yang perlu berperan aktif adalah penyedia jasa transportasi. Angkutan umum yang ada, sejauh ini hanya melewati beberapa lokasi SDA. Pangkalan ojek tersedia di mana-mana dan bisa 
dikemas untuk transportasi wisata warisan budaya.

Para pengojek menunggu penumpang di pangkalan masing-masing, hanya saja paketnya ditambah dengan sewa sepeda motor untuk mengunjungi objek wisata warisan budaya. Penyewa bisa mengendarai sendiri atau diantar pengojeknya. Mengendarai sepeda motor ke berbagai objek warisan budaya di Sangsanga merupakan pengalaman yang mengasyikkan. Apalagi jalanan di perbukitan menuju ke lokasi yang masih berupa jalan tanah, dapat menjadi pengalaman baru yang menyenangkan.

Cara ini dilakukan dengan mengadopsi lava tour di Kaliurang, Sleman, Yogyakarta. Lava tour bisa dilakukan dengan menyewa sepeda motor atau mobil Jeep. Sepeda motor, biasanya dikendarai sendiri oleh penyewanya, sedangkan Jeep dikemudikan oleh pemilik, dan semua penyewa menjadi penumpangnya. Keuntungan menyewa Jeep adalah mendapatkan informasi dan cerita tentang objek yang dikunjungi dari pengemudinya. Pengalaman yang pernah diperoleh dari lava tour, bahwa cerita yang disampaikan pengemudi tampak sepeti reportase karena memang mereka orang lokal yang mengalami kejadian bencana meletusnya Gunung Merapi.

Hal yang sama, saya kira bisa dilakukan kepada penyedia jasa transportasi di Sangasanga. Dalam hal ini yang perlu dilakukan adalah tambahan bekal pengetahuan yang bisa diperoleh dari Balai Arkeologi, Balai Pelestarian Cagar Budaya, Dinas Kebudayan dan Pariwisata setempat dan bahkan bisa juga digali dari para pejuang dan bekas karyawan tambang yang sekarang ini masih ada. Semua pengetahuan tersebut akan menjadi cerita yang menarik yang dapat disampaikan kepada para penyewa kendaraan untuk megunjungi objek wisata warisan budaya di Sangasanga.

Berkaitan dengan sarana penunjang kepariwisataan, seperti restoran, pramuwisata, dan hotel, fasilitas belum tersedia secara memadai. Restoran sudah tersedia tetapi sampai dengan saat ini pilihannya belum banyak.
Pramuwisata hingga saat ini tampaknya masih kurang jumlahnya. Seiring dengan dibukanya pariwisata, akan bermunculan usaha di bidang ini. Hotel belum tersedia, sebagai gantinya penginapan sederhana berupa rumah dan villa yang bisa difungsikan sebagai salah satu alternatif penginapan. Pilihan ini bisa memberikan nilai lebih bagi wisatawan. Caranya adalah dengan melengkapi villa yang difungsikan untuk penginapan dengan informasi tentang sejarah pertambangan minyak di Sangasanga. Foto-foto dan beberapa alat peraga pertambangan yang berukuran kecil, ditaruh di kompleks villa tersebut. Objek tersebut akan menjadi pelengkap informasi kepariwisataan Sangasanga, sekalipun pada saat suasana santai di penginapan.

Berkaitan dengan ketersediaan paket wisata, Sangasanga memiliki objek wisata museum yang memang sudah dibuka untuk umum dan ada juga pemandian air panas. Bahkan jika dikaitkan dengan objek wisata di kabupten, terdapat kegiatan tahunan yang cukup terkenal, yaitu erau. Tahun 2015 ini, erau dilaksanakan dengan mengundang kesenian dari berbagai daerah di Indonesia, sekaligus dipromosikan kepada seluruh masyarakat Indonesia dan juga luar negeri. Kejadian ini juga merupakan saat yang tepat untuk mempromosikan wisata warisan budaya di Sangasanga. Demikian juga dengan objek wisata lain di Tenggarong seperti Pulau Kumala, dan Kraton Kutai Kartanegara. Keberadaan beberapa objek wisata tersebut dapat menjadi paket wisata yang bisa ditawarkan kepada para turis.

Banyak aktivitas yang bisa ditawarkan untuk wisatawan di lokasi wisata. Antara lain menikmati keunikan, melihat proses pertambangan yang masih berlangsung, menikmati suasana pertambangan dengan seluruh kebiasaankebiasaannya yang meliputi suasana keberangkatan di pagi hari, suara soling yang menandakan saat masuk kerja, istirahat dan pulang kantor. Lengkingan suara soling akan diikuti oleh rutinitas yang khas dari para karyawan tambang, yaitu karyawan Pertamina 
UBEP Sangasanga, yaitu penjemputan, jalanan menjadi sibuk dan kemudian lengang karena semua karyawan masuk kerja, dan menjadi sangat ramai lagi karena semua karyawan keluar untuk istirahat, mencari makan atau pun pulang.

Aktivitas lain yang bisa ditawarkan adalah menjelajahi objek wisata warisan budaya dengan melewati jalanan beraspal dan sebagian jalan tanah, datar dan sebagian turun-naik di perbukitan yang di kanan dan kirinya banyak ditemui pompa angguk yang masih aktif. Selain itu, wisatawan juga dapat menyusuri Gua Jepang di Sangasanga Muara.

Pelayanan pendukung di Sangasanga sudah cukup memadai. Ada banyak pilihan bank untuk transaksi dan juga pengambilan kas. Layanan pos cukup lancar dan telekomunikasi dijangkau oleh berbagai macam penyedia jasa telekomunikasi. Pelayanan di bidang kesehatan tampaknya masih kurang. Pelayanan kesehatan di Sangasanga saat ini dilakukan di rumah sakit peninggalan kolonial Belanda. Rumah sakit ini memiliki sedikit tenaga medis. Padahal gedungnya luas sehingga banyak ruangan yang tidak terpakai. Rumah sakit ini masih bisa dikembangkan untuk meningkatkan layanan kesehatan dan juga layangan pendukung di bidang usaha wisata.

Untuk promosi wisata, yang baru bisa diandalkan adalah museum, wisata perjuangan dan wisata air panas. Sejauh ini promosi wisata melalui leaflet, iklan di koran, radio atau televisi belum pernah dilakukan. Selanjutnya, dalam rangka mewujudkan Sangasanga sebagai daerah tujuan wisata budaya, perlu melengkapi fasilitas-fasilitas yang masih kurang, sehingga memenuhi standar kelengkapan fasilitas bagi pengunjung dan layak dipromosikan menjadi daerah tujuan wisata.

\section{Membiasakan Masyarakat Memanfaatkan SDA yang Bersifat Melestarikan}

Salah satu cara agar masyarakat selalu memanfaatkan SDA dengan tindakan yang bersifat melestarikan adalah dengan memberi peluang untuk mendapatkan keuntungan dalam memanfaatkan SDA. Strateginya dilakukan dengan memberi peluang kepada masyarakat untuk memperoleh uang dan kesempatan untuk menempati bangunan yang dikategorikan sebagai warisan budaya. Selain itu, pemerintah membuat program yang mendorong masyarakat untuk membuka usaha yang memiliki keterkaitan dengan warisan budaya.

Semua itu akan dapat berjalan dengan efektif jika masyarakat yang memanfaatkan SDA benar-benar memperoleh keuntungan atas pemanfaatan yang dilakukan. Akan lebih efektif lagi jika masyarakat yang memperoleh keuntungan itu jumlahnya banyak. Diharapkan dengan adanya keuntungan yang diperoleh akan membuka kesadaran masyarakat sehingga mereka memiliki tekad yang kuat untuk selalu melestarikan aset yang bisa mendatangkan keuntungan finansial.

\section{Strategi Pemanfaatan yang Melestarikan dan Paling Tepat}

Sub bahasan ini merupakan upaya menemukan strategi yang paling tepat untuk diimplementasikan dalam pemenfaatan sekaligus pelestarian. Berdasarkan uraian di atas, SDA yang berupa bangunan dimanfaatkan dengan cara dijadikan sebagai tempat tinggal, perkantoran, gedung pertemuan, bengkel, dan rumah sakit. Idealnya, bangunaan yang digunakan akan dirawat sehingga kelestariannya terjaga. Faktanya ada bangunan yang dimanfaatkan, tetapi kondisinya semakin rusak. Permasalah ini harus diketahui penyebabnya agar dapat diberikan solusi yang tepat.

Bangunan yang terawat dengan baik adalah bangunan yang digunakan untuk kantor Pertamina UBEP, perumahan karyawan Petamina UBEP, bengkel, Gedung Pembangkit Tenaga Listrik (PTL) Elektra, gedung Sandisa yang sekarang difungsikan sebagai gedung pertemuan, sebagian tangsi, rumah orang Belanda yang dimiliki perorangan yang diperoleh dengan cara membeli, dan bangunan yang telah dicagarbudayakan (misalnya penjara). Sementara itu, bangunan yang termasuk dalam 
kategori warisan budaya yang dimanfaatkan tetapi justru kondisinya semakin rusak antara lain barak, tangsi, komplak, dan rumah sakit.

Jika diperhatikan penyebabnya, hingga terjadi perbedaan antara bangunan yang terawat dan yang semakin rusak, tampaknya terlihat pada ketersediaan anggaran untuk perawatan. Berdasarkan informasi yang diperoleh, diketahui bahwa perusahaan memiliki anggaran untuk perawatan dan bahkan renovasi. Biasanya untuk perawatan meliputi pekerjaan membersihkan, pengecatan ulang, dan perbaikan yang tidak menyangkut konsruksi bangunan, dapat dilakukan dengan cukup memberikan laporan ke Pertamina UBEP Sangasanga dan kemudian diberikan dana untuk biaya peawatan tersebut. Jika perbaikan mencapai nilai biaya yang tinggi atau berkaitan dengan konstruksi bangunan, diputuskan di Pertamina Pusat. Contoh, pada renovasi dan penambahan bangunan baru di PTL yang pekerjaannya ditenderkan. Informasi dari pihak Humas Pertamina menyebutkan bahwa ramburambu dalam renovasi yang selalu dilaksanakan adalah mempertahankan bentuk. Dengan demikian, spesifikasi lelang memuat konsep renovasi yang mempertahankan bentuk. Jika memperhatikan hasil renovasi, maka bentuk bangunan PTL masih dipertahankan, sedangkan penambahan bangunan baru diletakkan pada areal yang terpisah dengan bangunan lama.

Selain itu, ada salah satu ruangan tangsi yang dipinjam penduduk masih dalam keadaan terawat dengan baik. Keterawatan ruangan di tangsi yang berada di dekat Jalan Jenderal Sudiman ini karena memang pihak peminjam memiliki penghasilan yang cukup untuk memenuhi kebutuhan rumah tangganya dan juga untuk perawatan tangsi yang dipinjamnya. Perawatan dan perbaikan juga dilakukan sebatas pada mememuhi kenyamanan tinggal. Misalnya, atap sirap yang bocor. Karena harga sirap cukup mahal, perbaikan dilakukan dengan memberi lapisan seng gelombang di atas sirap.

Perbaikan juga dilakukan pada bagian lantai dengan meninggikan lantai hingga selutut orang dewasa (sekitar $50 \mathrm{~cm}$ ) di separuh ruang tamu bagian belakang. Latar belakang dilakukan penambahan tinggi lantai karena saat terjadi hujan lebat air menuju ke arah tangsi yang memang posisinya lebih rendah daripada jalan di depannya. Dengan meninggikan lantai, maka ketika air masuk ke ruangan tangsi, barangbarang akan diamankan di lantai yang agak tinggi tersebut.

Semakin lama, kondisi tersebut dirasa kurang nyaman sehingga dilakukan perbaikan dinding terluar, dengan cara mengganti dinding bahan papan dengan bata. Penggantian bahan dinding dilakukan dengan cara melepas tiga lajur papan terbawah untuk kemudian diganti dengan dinding dari bahan bata. Penggantian ini dimaksudkan untuk mencegah masuknya air ke ruangan. Dengan mengganti dinding kayu setinggi tiga lajur papan (sekitar $45 \mathrm{~cm}$ ), maka air tidak masuk ke ruangan lagi.

Tangsi yang demikian ini dikategorikan dalam keadaan terawat karena secara keseluruhan kondisinya memang masih baik. Sementara itu, perbaikan yang dilakukan masih dapat dikembalikan lagi ke keadaan semula. Pada bagian atap tinggal melepas seng gelombang dan kemudian diganti dengan atap sirap. Sementara itu untuk lantai di ruang tamu, perbaikan tinggal meratakan kembali lantai, demikian juga pada dindingnya. Mengenai perbaikan dan penambahan pada tangsi, menurut pihak peminjam diperbolehkan karena yang dilakukan tidak mengubah bentuk bangunan. Hal itu dibuktikan dengan bentuk atap dan bangunan yang masih sama seperti dulu.

Rumah Belanda yang sekarang dimiliki perorangan juga masih dalam kondisi baik dan terawat. Bahkan pemilik mengaku selalu berusaha memperbaiki jika ada kerusakan. Hal ini selalu dilakukan karena rumah tersebut diakui menjadi miliknya dan yang bersangkutan harus bertanggung jawab. Tampaknya inilah alasanalasan atau latar belakang terpeliharanya bangunan purbakala di Sangasanga. 
Sementara itu mengenai Rumah Sakit yang sekarang ini masih digunakan oleh Pertamina UBEP Sangasanga dikategorikan tidak terawat. Tampaknya kompleks bangunan itu tidak difungsikan secara keseluruhan. Hal ini karena sedikitnya tenaga medis, sehingga ada ruangan atau gedung yang tidak terpakai. Gedunggedung yang tidak terpakai inilah yang kemudian tidak terawat dengan baik, misalnya bagian atap dimakan rayap.

Sementara itu bangunan bangsal, barak, sebagian tangsi, dan komplak, banyak yang mengalami kerusakan. Para penghuni umumnya tidak melakukan perbaikan karena tidak memiliki dana untuk keperluan itu. Contoh, Bangsal B21 dekat Jalan Jenderal Sudirman. Bangsal ini keadaannya rusak berat, akan tetapi tidak ada perbaikan. Umumnya mereka mengaku tidak punya biaya, dan berharap pihak pemilik (Pertamina UBEP) yang akan memperbaikinya.

Sebagian bangsal juga ada yang diperbaiki oleh penghuninya, akan tetapi kondisinya tetap dikategorikan rusak. Perbaikan yang dilakukan justru menjadikan berubahnya bentuk dan keaslian bangunan, terutama pada bahan (material). Perubahan bentuk terjadi pada Bangsal 13 di Bangsal Hutan di Jalan Teratai. Atap bangsal yang rusak diganti atap baru yang posisinya dibawah atap lama. Bangunan itu sekarang berada di bawah kerangka atap bangunan lama serta di antara tiang-tiang bangunan lama. Perbaikan itu memunculkan bangunan baru dengan bahan batako, yang lokasinya berada di dalam bangunan lama. Sehingga terjadi penggantian bahan dinding pada bangunan lama berupa asbes, dengan dinding dari bahan batako. Penggantian tersebut mengakibatkan bangunan menjadi tidak asli lagi. Perubahan-perubahan itu menyebabkan Bangsal 13 dinyatakan mengalami kerusakan.

Kenyataan ini, menunjukan pemanfaatan dan pelestarian SDA di Sangasanga belum seperti yang diharapkan. Sebenarnya yang terjadi sekarang ini merupakan permasalahan pertama dalam tulisan ini, yaitu pemanfaatan dengan cara dijadikan tempat tinggal atau sebagai kantor. Namun demikian, konsekuensi yang diperoleh tidak seperti yang diharapkan, yaitu salah perawatan atau tidak dilakukan perawatan sehingga tidak terwujud kegiatan pelestarian. Hal itu disebabkan tidak ada kontrol, sehingga penghuni bisa melakukan apa saja tanpa batasan-batasan yang jelas. Padahal, kontrol itulah yang akan mengarahkan langkah dalam pemanfaatan dan pelestarian. Kontrol itu akan lebih mudah dan efektif dijalankan apabila menggunakan peraturan. Untuk itu, UndangUndang Nomor 11 tahun 2010 tentang Cagar budaya diperlukan. Undang-undang tersebut akan efektif digunakan jika SDA yang ada telah dicagarbudayakan. Oleh karena itu, dalam rangka pemanfaatan yang bersifat melestarikan, SDA di Sangasanga perlu segera dicagarbudayakan.

Berkaitan dengan pemanfaatan yang memberi nilai tambah adalah dengan menjadikan SDA sebagai objek wisata warisan budaya. Diakui bahwa cara ini juga memungkinkan menjadi penyebab kerusakan warisan budaya, misalnya karena ulah pengunjung yang kurang bertanggungjawab serta kelebihan beban karena banyaknya pengunjung. Berkaitan dengan itu, upaya untuk menghindari kerusakan warisan budaya dapat dilakukan antisipasi yang berupa pengawasan dan edukasi. Pengawasan dilakukan Dinas setempat dan Balai Pelestarian dengan bantuan tenaga keamanan dan masyarakat yang tinggal atau memanfaatkan bangunan itu.

Sementara itu, terwujudnya kegiatan pemanfaatan yang bersifat melestarikan perlu diupayakan dan diimplementasikan oleh masyarakat sekitar SDA agar menjadi suatu bagian dari rutinitas kehidupan. Dalam hal ini dilakukan dengan menciptakan langkah yang bermanfaat untuk menaikkan tingkat kepercayaan kepada masyarakat, misalnya melakukan pemanfaatan hingga memperoleh keuntungan sehingga kemudian dengan penuh kesadaran yang bersangkutan akan melakukan tindakan. 
Tampaknya kegiatan lava tour merupakan contoh pemanfaatan oleh masyarakat yang sekaligus berdampak melestarikan. Pengamatan terhadap objek-objek yang dikunjungi dalam kegiatan lava tour merupakan upaya mengkonstruksi pola pikir masyarakat dalam memanfaatkan sumberdaya wisata, mendapatkan nilai tambah, dan menjadikannya sebagai bagian hidup karena dari situlah penghidupan disandarkan. Jika polanya sudah seperti ini, maka kegiatan yang bersifat melestarikan, menjadi suatu konsekuensi logis yang mesti dilakukan oleh masyarakat yang memanfaatkan sumber daya itu.

Dalam konteks lava tour, konstruksi yang dilakukan adalah mengedukasi/mendidik masyarakat Kaliurang, Yogyakarta yang tertimpa bencana meletusnya Gunung Merapi agar memanfaatkan barang-barang yang rusak akibat bencana tersebut. Hasilnya, ada rumah yang masih menyisakan tembok dan sebagian sudah tanpa atap, kemudian diisi perkakas rumah yang tersisa dan dalam kondisi rusak oleh awan panas akibat meletusnya Gunung Merapi. Barangbarang yang rusak tersebut ditata dan diberi tulisan-tulisan pendek yang menginformasikan benda dan situasi yang terjadi. Di tembok rumah yang rusak itu juga dituliskan hasil pengalaman dan renungan yang mengingatkan kita agar selalu waspada terhadap kemungkinan meletusnya Gunung Merapi. Misalnya tulisan yang berbunyi,"Merapi tak pernah ingkar janji". Dalam pengalaman masyarakat Kaliurang, Merapi pasti akan meletus atau mengeluarkan awan panas, entah dalam siklus berapa tahun, tetapi itu diyakini pasti akan terjadi lagi. Siklus itu, tidak pernah diingkari oleh Merapi.

Kemasan salah seorang warga lereng Merapi di Kaliurang tersebut, kini telah dikunjungi oleh ribuan orang. Sebenarnya, lokasinya tidak terlalu mudah untuk dijangkau. Akan tetapi, dengan persediaan sewa sepeda motor trail atau mobil Jeep, lokasinya memungkinkan dijangkau. Walaupun jalanan berdebu, tetapi Jeep-Jeep dan trail berseliweran di lereng Merapi. Keunikan, jalanan yang sulit, cerita tentang bencana
Merapi, semua itu dikemas menjadi daya tarik yang mendatangkan keuntungan, sehingga mereka yang memperoleh keuntungan finansial dari daerah tersebut dipastikan akan rela untuk turut merawat sumberdaya yang mendatangkan keuntungan tersebut. Dengan cara ini, masyarakat pemilik rumah yang dikunjungi, penjual cindera mata dan makanan, pemilik persewaan motor dan Jeep, para supirnya dan semua yang terkait dengan pariwisata itu diyakini akan rela untuk turut melestarikan, dan menjadikan itu sebagai perilaku dalam menjalani kehidupannya. Seperti halnya yang dituangkan dalam tulisan Saputra (2014), bahwa ada juga sebagian orang yang tidak sepakat dengan kegiatan lava tour. Barangkali sebagian warga yang tidak sependapat adalah mereka yang belum merasakan keuntungan atas kegiatan tersebut.

Berkaca dari model mengonstruksi seperti di atas, edukasi terhadap masyarakat Sangasanga dalam pengembangan pariwisata warisan budaya dapat meniru model tersebut. Dengan perbedaan kekuatan potensi dan persepsi masyarakat, diharapkan masih dapat meraih keberhasilan dalam pengembangan pariwisata warisan budaya di Sangasanga.

Berkaitan dengan bahasan mengenai strategi pemanfaatan yang tepat terhadap peninggalan arkeologi kolonial di Sangasanga adalah diterapkannya gabungan dari tiga subbahasan di atas, yaitu pemanfaatan yang bersifat melestarikan, memberi nilai tambah, dan membiasakan masyarakat agar selalu memanfaatkan SDA yang berwawasan pelestarian. Pertama adalah memberikan kesempatan kepada masyarakat untuk memanfaatkan SDA yang ada di lingkungan mereka. Kesempatan itu diberikan tidak cuma-cuma, yang bersangkutan harus diberi tanggung jawab untuk merawat SDA (misalnya rumah) yang dimanfaatkan (misalnya untuk tempat tinggal).

Kedua, masyarakat yang ada di lingkungan SDA ataupun anggota masyarakat yang menempati SDA (rumah), dilibatkan dalam program pengembangan pariwisata warisan 
budaya. Keterlibatan mereka dengan diberi peluang usaha secara perorangan yang jenis usahanya berkaitan dengan program pengembangan pariwisata warisan budaya, misalnya produksi dan penjualan cindera mata khas Sangasanga atau Kalimantan Timur. Di sini pemerintah tidak hanya memberi peluang, tetapi juga berperan aktif dalam pelatihan dan pinjaman modal usaha. Berbagai peluang usaha yang dibuka diupayakan bisa dikaitkan dengan program wisata warisan budaya. Maksudnya, berbagai usaha yang dibuka diharapkan memberikan kontribusi dalam pengembangan program pariwisata warisan budaya. Kontribusi dapat diwujudkan antara lain dengan turut memberikan informasi kepada pelanggan tentang wisata warisan budaya di Sangasanga, baik tentang content, cara mencapai lokasi, maupun berbagai daya tariknya. Tidak kalah penting adalah memberikan pelayanan yang ramah, serta turut menjaga ketertiban dan keamanan.

Peningkatan kualitas layanan dan pengembangan wisata warisan budaya sangat bermanfaat dalam upaya meningkatkan jumlah pengunjung. Selanjutnya, kepuasan para wisatawan dapat meningkatkan keinginan untuk mengulangi kunjungannya. Tidak hanya itu, mereka juga memungkinkan menjadi agen yang efektif bagi para kerabat, kolega dan siapa saja yang dikenalnya yang untuk menyampaikan pengalamannya, dan diharapkan mereka yang mendengar akan tertarik untuk mengunjungi Sangasanga. Dengan demikian, banyaknya pengunjung akan berimbas pada meningkatnya pendapatan bagi pelaku usaha.

Kaitan antara perilaku dan keuntungan yang mungkin diperoleh masyarakat inilah yang harus selalu digerakkan kepada segenap masyarakat Sangasanga. Jika banyak warga Sangasanga dapat menikmati keuntungan atas keberadaan dan pemanfaatan SDA, diharapkan mereka akan dengan suka rela melakukan penjagaan dan perawatan SDA karena keuntungan secara berkelanjutan akan mereka peroleh. Jika strategi ini dapat diterapkan dan dirasakan manfaatnya oleh masyarakat, target untuk membiasakan masyarakat melakukan penjagaan dan perawatan SDA yang memberikan keuntungan kepada mereka adalah suatu konsekuensi logis yang pasti akan dilakukan. Dengan demikian, pemanfaatan yang paling tepat yang dapat melestarikan SDA di Sangasanga adalah rangakaian tiga hal di atas, yaitu pemanfaatan, pemanfaatan yang memberi nilai tambah, dan membiasakan masyarakat mempraktekkan kegiatan pelestarian sebagai perilaku dalam hidup sehari-hari. Ketiganya berada dalam satu rangkaian pemanfaatan, tanggung jawab, dan perilaku yang menyatu dalam kehidupan masyarakat yang menguntungkan.

\section{Simpulan dan Saran Simpulan}

Berdasarkan uraian di atas, disimpulkan bahwa kegiatan yang dapat memberi manfaat untuk pelestarian SDA adalah dengan memberi peluang kepada masyarakat untuk memanfaatkan SDA (misalnya menempati rumah). Apabila seseorang menempati rumah, maka yang bersangkutan pasti akan melakukan perawatan terhadap rumah yang ditempatinya. Selain itu, hendaknya pihak yang berwenang memberikan izin penggunaan SDA tersebut juga meminta pengguna agar selalu melakukan perawatan sebagai kompensasi atas pemanfaatan yang telah dilakukannya.

Sementara itu, kegiatan pemanfaatan SDA yang dapat memberi nilai tambah bagi masyarakat dan sekaligus menjadi faktor penyebab terjadinya kegiatan pelestarian adalah memberi peluang untuk melakukan kegiatan ekonomi yang berlandaskan pada keberadaan SDA. Contohnya menjadikan SDA di Sangasanga sebagai objek wisata warisan budaya. Selain kegiatan yang berkaitan langsung dengan SDA seperti tersebut di atas, perlu pula didukung untuk dikembangkan kegiatan ekonomi yang tidak langsung berkaitan dengan SDA, misalnya kegiatan perdagangan di lokasi wisata, jasa penginapan, transportasi dll. Diharapakan dengan adanya keberadaan SDA yang dapat menciptakan kegiatan yang mendatangkan nilai 
tambah bagi masyarakat, mereka akan dengan suka rela turut melakukan perawatan SDA yang telah memberikan keuntungan bagi mereka.

Cara mengimplementasikan kegiatan pemanfaatan yang tidak terpisahkan dari pelestarian dapat menjadi kebiasaan dalam kehidupan masyarakat adalah dengan memberi peluang sebanyak-banyaknya kepada masyarakat untuk dapat turut serta memanfaatkan atau pun mengambil manfaat atas keberadaan SDA di Sangasanga, seperti memberi peluang usaha (terkait keberdaan SDA), kepada masyarakat sebanyak mungkin. Semakin banyak pihak mendapatkan keuntungan akan semakin banyak yang peduli dengan SDA. Imbasnya, akan semakin efektif keterlibatan masyarakat dalam kegiatan pelestarian. Intensitas yang tinggi dalam kegiatan pelestarian juga akan berdampak pada terciptanya kebiasaan kehidupan masyarakat dalam melestarikan SDA.

Selanjutnya, langkah yang perlu dilakukan untuk memperbanyak dan menguatkan keterlibatan masyarakat dalam pemanfaatan dan pelestarian SDA adalah dengan menerapkan gabungan dari ketiga hal di atas. Harus dilakukan pemberian kesempatan kepada masyarakat untuk memanfaatkan SDA, menjadikannya sebagai objek wisata warisan budaya, memberi peluang kepada masyarakat untuk melakukan kegiatan ekonomi yang berkaitan dengan SDA, dan yang tidak kalah penting adalah untuk terus-menerus dilakukan edukasi kepada masyarakat, monitoring, dan evaluasi untuk memperoleh peningkatan pelestarian SDA. Dengan pengawasan yang ketat dan evaluasi yang terus-menerus, diyakini bahwa upaya pemanfaatan yang bersifat melestarikan dapat dicapai.

\section{Saran}

Berdasarkan hasil kajian, disarankan agar segera mengimplementasikan pemanfaatan yang berdampak pada pelestarian SDA. Mendorong masyarakat agar berpartisipasi dalam pelestarian dan memperoleh keuntungan dari kegiatan tersebut. Selain itu masyarakat juga didorong untuk menerapkan kegiatan pelestarian sebagai bagian dari habit. Selanjutnya, pengawasan dan evaluasi secara terus-menerus harus dilakukan agar diperoleh keberhasilan program.

\section{PUSTAKA ACUAN}

Agustina, N.K.W. 2012. Desa Budaya Kertalangu Sebagai Usaha Daya Tarik Wisata di Kota Denpasar. Tesis. Denpasar: Program Pascasarjana, Universitas Udayana.

Ahyat, I.S., 2013. Kesultanan Kutai 1825-1910 Perubahan Politik dan Ekonomi Akibat Penetrasi Kekuasaan Belanda. Tangerang: Serat Alam Media.

Arini, D., Arief, A.T., \& Prabu, U.A. 2015. Desain Sucker Rod Pump Untuk Optimasi Produksi Sumur Sembur Alam L5A-X Di Pertamina EP Asset 2 Field Limau. Jurnal Ilmu Teknik, 3 (1), hlm. 15-23.

Dini, N.Z. 2012. GKI Kwitang: Tinjauan Arsitektur dan Pemugaran dalam Rangka Pelestarian Bangunan Cagar Budaya. Skripsi. Depok: Program Studi Arkeologi,Fakultas Ilmu Pengetahuan Budaya, Universitas Indonesia.

Endraswara, S. 2006. Metode Penelitian Kebudayaan. Yogyakarta: Gadjah Mada University Press.

Faisal, G. \& Wihardyanto, D. 2013. Selembayung Sebagai Identitas Kota Pekanbaru: Kajian Langgam Arsitektur Melayu. Indonesian Journal of Conservation, 2 (1), hlm. 51-59.

Gunamantha, I.M., \& Susila, G.P.A.J. 2015. Analisis Dampak Program Pengembangan Kecamatan Terhadap Pengentasan Kemiskinan Di Kabupaten Buleleng. Jurnal Ilmu Sosial dan Humaniora, 4 (1), hlm. 523-533. 
Harjiyani, F.R. \& Raharja, S. 2012. Perlindungan Hukum Benda Cagar Budaya Terhadap Ancaman Kerusakan di Yogyakarta. Jurnal Mimbar Hukum, 24 (2), hlm.345-356.

Hayati, R. 2014. Pemanfaatan Bangunan BersejarahSebagai Wisata Warisan Budaya di Kota Makassar. Jurnal Master Pariwisata (Jumpa), 1 (1), hlm.1-42.

Jaya, D.P. 2012. Model Pemanfaatan Sumberdaya Arkeologi Sebagai Objek Daya Tarik Wisata Studi Kasus Candi Sukuh. Tesis. Yogyakarta: Program Studi Ilmu Arkeologi, Fakultas Ilmu Budaya, Universitas Gadjah Mada.

Kadarwati, A. 2008. Potensi dan Pengembangan Obyek Wisata Kota Lama Semarang Sebagai Daya Tarik Wisata di Semarang. Laporan Tugas Akhir. Surakarta: Jurusan DIII Usaha Perjalanan Wisata, Fakultas Sastra Dan Seni Rupa, Universitas Sebelas Maret.

Moloeng, L.J. 2014. Metodologi Penelitian Kualitatif Edisi Revisi. Bandung: Remaja Rosdakarya.

Muttaqin, L.A. 2014. Model Pelestarian Berdasarkan Perundang-undangan: Studi Kasus Kawasan Cagar Budaya Kotagede, Yogyakarta. Skrips. Yogyakarta: Program Studi Ilmu Arkeologi, Jurusan Arkeologi, Fakultas Ilmu Budaya, Universitas Gadjah Mada.

Nuryanti, W. \& Suwarno, N. 2008. Kajian Zonasi Pengembangan Kawasan Pusaka Studi Kasus: Situs Sangiran, Sragen. Jurnal Manusia dan Lingkungan, 15 (3), 101-110.

Panggabean, A.S. 2014. Perubahan Fungsi dan Struktur Bangunan Cagar Budaya Ditinjau dari Perspektif Undang-Undang Cagar Budaya. Pandecta: Jurnal Penelitian Ilmu Hukum, 9 (2), hIm. 169-181.

Primadani, E., Larasati S.E., Subowo, A. 2013. Analisis Manajemen Strategi Pelestarian dan Pengembangan Kawasan Kota Lama Sebagai Upaya Menuju Kawasan Wisata Budaya di Kota Semarang. Journal Public of Policy and Management Review, 2 (2), hlm. 141-150.

Purnawibowo, S. 2014. Strategi Pengelolaan Kawasan Kota Cina, Medan, Sumatera Utara Berbasis Masyarakat. Tesis. Yogyakarta: Program Studi Arkeologi, Fakultas Ilmu Budaya, Universitas Gadjah Mada.

Rachmawati, I.N. 2007. Pengumpulan Data Dalam Penelitian Kualitatif: Wawancara. Jurnal Keperawatan Indonesia, 11 (1), hlm.35-40.

Rahardjo, T. 2011. Konstruksi Teori (Komunikasi) dalam Logika Hypothetico-Deductive. Jurnal Ilmu Komunikasi, 8 (2), hlm.107-124.

Saleh, I.N.S. 2004. Kajian Aspek Hukum Konservasi Cagar Budaya Terhadap Pelestarian dan Pengembangan Pariwisata Kotagede. Tesis.Yogyakarta: Program Studi Ilmu Hukum, Fakultas Hukum, Universitas Gadjah Mada.

Saputra, Y. 2014. Jeep Wisata di Kawasan Wisata Lava Tour Pasca Erupsi Merapi Tahun 2010 (Studi pada Kawasan Wisata Kaliurang, Hargobinangun, Pakem, Sleman). Skripsi.Yogyakarta: Fakultas Ilmu Sosial, Universitas Negeri Yogyakarta.

Suryono, A. 2012. Pelestarian Arsitektur Museum Sonobudoyo Yogyakarta. Laporan Penelitian. Bandung: Lembaga Penelitian dan Pengembangan kepada Masyarakat, Universitas Katolik Parahiyangan.

Susanto, N.N. 2005. Penelitian Aspek Keruangan Pola Tata Kolonial Sanga-sanga di Kabupaten Kutai Kartanegara, Provinsi Kalimantan Timur. Laporan Penelitian Arkeologi. Banjarbaru: Balai Arkeologi Banjarmasin.

Suweda, I. W. 2011. Penatan Ruang Perkotaan yang Berkelanjutan, Berdaya Saing dan Berotonomi. Jurnal IImiah Teknik Sipil, 15 (2), hlm.113-122. 
Tim Peneliti. 2008. Permukiman dan Industri Pertambangan: Pengaruh Kolonial di Kalimantan Timur. Laporan Penelitian Arkeologi. Jakarta: Puslitbang Arkenas.

Tim Penyusun Kamus Pusat Pembinaan dan Pengembangan Bahasa. 1995. Kamus Besar Bahasa Indonesia. Edisi kedua. Jakarta: Balai Pustaka.

Undang-Undang Republik Indonesia Nomor 10 Tahun 2009 tentang Kepariwisataan.

Undang-Undang Republik Indonesia Nomor 11 Tahun 2010 tentang Cagar Budaya. Jakarta: diperbanyak tahun 2011 oleh Kementerian Kebudayaan dan Pariwisata.

Wardi, I.N. 2008. Pengelolaam Warisan Budaya Berwawasan Lingkungan: Studi Kasus Pengelolaan Living Monument di Bali. Jurnal Bumi Lestari, 8 (2), hlm. 193-204.

Wasita, Kusmartono, V.P.R., Hartatik, Ma'rifat, T.A., \& Septiani, A. 2012. Persepsi Para Stakeholder dalam Pelestarian Situs Sanga-sanga, di Kabupaten Kutai Kartanegara, Kalimantan Timur. Laporan Penelitian Arkeologi. Banjarbaru: Balai Arkeologi Banjarmasin.

Widiyati, Wasino. 2011. Pemberdayaan Masyarakat untuk Berpartisipasi dalam Pelestarian Situs Patiayam di Kabupaten Kudus. Paramita: Jurnal Sejarah dan Pembelajaran Sejarah, 21 (1), hlm. 51-60.

Widyawati, L. N. \& Syahbana, J.A. 2013. Keseriusan dan Konsekuensi Sikap Pemerintah Daerah Terhadap Pelestarian di Kawasan Kota Lama Semarang. Jurnal Teknik PWK, 2 (2), hlm.303-313.

Wiraprama, A.R., Zakaria, \& Purwantiasning, A.W. 2014. Kajian Pola Permukiman Dusun Ngibikan Yogyakarta Dikaitkan dengan Perilaku Masyarakatnya. Jurnal Arsitektur NALARs, 13 (1), hlm. 31-36.

Wiratmoko, A.B. 2012. Pengaruh Taman Wisata Candi Borobudur Terhadap Kondisi Kehidupan Sosial Ekonomi Masyarakat Kabupaten Magelang 1980-1997. Jurnal of Indonesian History, 1 (2), hlm. 125-133. 